\title{
EVALUATING MANAGEMENT SYSTEMS AND THE INTANGIBLE PERFORMANCE OF ORGANIZATION INFLUENCED BY THE ENTERPRISE RESOURCE PLANNING
}

\author{
Morteza Mousakhani ${ }^{1}$ \\ Arash Rahmani $^{2}$ \\ Nazanin Rahmani ${ }^{3}$ \\ Kiumars Mazhar ${ }^{4}$
}

\begin{abstract}
This study investigates the effects of enterprise resource planning systems adoption on Intangible performance of a firm. Specifically, the role of informal management control systems is investigated as mechanisms which mediate the effect of enterprise resource planning systems adoption on intangible performance of a firm. The empirical analyses of this study are based on survey data drawn from 4 companies that were collected by questionnaire. This study test our structural equation model using the multivariate statistical method Partial Least Squares (PLS) .The findings of this study demonstrate that informal types of management control
\end{abstract}

systems do not mediate the positive effect between enterprise resource planning systems adoption and Intangible performance. These results are very important because the evidence on the joint roles of enterprise resource planning systems and management control system on improving the firm performance is very limited in prior literature. The results of this study show that the use of enterprise systems results in improved firm performance in the long run, and that more formal than informal types of management controls help firms achieve future performance goals.

\footnotetext{
${ }^{1}$ Department of Management, Qazvin Branch, Islamic Azad University, Qazvin, Iran. Email: mousakhani.mr@gmail.com

${ }^{2}$ Department of Management, Qazvin Branch, Islamic Azad University, Qazvin, Iran. Email: mousakhani.mr@gmail.com.

${ }^{3}$ Department of Management, Qazvin Branch, Islamic Azad University, Qazvin, Iran. Email: mousakhani.mr@gmail.com.

${ }^{4}$ Department of Management, Qazvin Branch, Islamic Azad University, Qazvin, Iran. Email: mousakhani.mr@gmail.com.
} 


\section{1- Introduction}

Organizations are met with increasing demands for being in strategic control. To live up to these demands, numerous efforts have been undertaken, including the design and implementation of management information systems. These systems, as epitomized in Enterprise Resource Planning (ERP) systems, seek to bring the organization under strategic control by creating a unified infrastructure for collecting and analyzing data from virtually all fields of organizational operations to enable planning and monitoring of activities (Kallinikos, 2006).

ERPSs are organization-wide and integrated information systems that can be used to manage and coordinate all the resources, information, and functions of a business from shared data stores. As ERPSs are intended to integrate all corporate information into one central database, they allow all information to be retrieved from many different organizational positions and to make any organization object visible (Dechow and Mouritsen, 2005).

Regarding to the point that investment is for implementation and operation from macro-ERP systems and infrastructures, does not perform its influence over the short period. So, some of managers conclude that the project has not prospered after a short while and applying this system has not been effective.

But the fact is that ERP systems firstly influence on intangible performance factors and show its effects after a long time. On the face of it, important factors of enterprise intangible performance should be recognized in order to exact assessment of ERP systems effects on enterprise function. Therefore, managers should consider intangible performance aspects while evaluating of ERP systems.

On the other hand, When ERPS are used in tandem with an efficient portfolio of controls, they may achieve an organization's objectives and lead to improvements in performance (Kallunki et al., 2010). So the evaluation of the role of management control systems on the relationship between organizational performance and ERP systems would be important and essential.

MCS is a system which gathers and uses information to evaluate the performance of different organizational resources - human, physical, financial and also of the organization as a whole - 
considering the organizational strategies (Kallinikos, 2006). The main purpose of MCS is to is to provide information useful for decision making, planning and evaluation (Merchant and Otley, 2006), so as to control decisions throughout the organization and guide behavior in desirable ways in order to help organizations achieve their objectives (e.g. Anthony and Govindarajan, 2007; Bhimani et al., 2008).

\section{2- Literature review and hypotheses development}

\section{2-1 Enterprise Resource Planning}

\section{Systems}

ERP systems will create central oversight by giving managers constantly up-dated, highly detailed and easily accessible data on operations (Clemmons \& Simon, 2001). This means that ERP implementations often place increased demands for accountability and self-control on lower level managers, as the system enables everyone to see, plan and manage their own spending and production (Caglio, 2003).

Some of the capabilities of the enterprise resource planning's systems are as follows (Adel Azar and Jahanian, 1390):

- Enterprise resource planning system, will facilitate the establishment of integrated information system across the entire company, so that covers all functional areas such as manufacturing, sales and distribution, receivable and payable accounts, inventory, human resources and procurement.

Enterprise resource planning system runs the main business activity of the enterprise and increases customer service that ultimately leads to improving the image of the organization to customers.

- Enterprise resource planning system fills the information gap across the organization.

- Enterprise Resource Planning systems, provides system integration, not only for the organization units but also for a variety of companies that have the same management.

Enterprise resource planning system is one of the possible solutions to better project management.

Enterprise resource planning system enables the automatic application of the latest technologies, such as electronic funds transfer, cash, electronic 
data interchange, Internet, intranet, video conferencing and e-commerce.

- $\quad$ Enterprise resource planning systems, settle most of the business problems like Material shortages, improving productivity, quality and timely delivery failure of orders.

- Enterprise resource planning system, considers not only the current needs but also opportunities for continuous improvement of business processes.
- Enterprise resource planning systems, provides intelligent business tools such as decision's support systems, information systems of senior managers, reporting, data mining and early warning systems (robots). These are provided to help people make better decisions and thus improve their work processes.

The benefits of ERP systems are listed in Table 1.

Table 1: Advantages of ERP systems (Mohammad A. Rashid et al.,2002)

\begin{tabular}{|c|l|l|}
\hline NO. & \multicolumn{1}{|c|}{ benefit } & \multicolumn{1}{c|}{ How } \\
\hline 2 & Reliable information access & $\begin{array}{l}\text { Common DBMS, consistent and accurate data, improved } \\
\text { reports. }\end{array}$ \\
\hline 3 & $\begin{array}{l}\text { Dvoid data and operations } \\
\text { redundancy }\end{array}$ & $\begin{array}{l}\text { Modules access same data from the central database, } \\
\text { avoids multiple data input and update operations. }\end{array}$ \\
\hline 4 & Cost reduction & Minimizes retrieving and reporting delays \\
\hline 5 & Easy adaptability & $\begin{array}{l}\text { Time savings, improved control by enterprise wide } \\
\text { analysis of organizational decisions. }\end{array}$ \\
\hline 6 & Improved maintenance & $\begin{array}{l}\text { Changes in business processes easy to adapt and } \\
\text { restructure. }\end{array}$ \\
\hline 7 & Global outreach & Sendor-supported long-term contract as part of the \\
\hline 8 & E-Commerce, e-business & Extended modules such as CRM and SCM. \\
\hline
\end{tabular}


Table 2 summarizes the researches done on the relationship between enterprise resource

\begin{tabular}{|c|c|c|}
\hline NO. & Result of research & $\begin{array}{l}\text { Researches } \\
\text { name }\end{array}$ \\
\hline 1 & $\begin{array}{l}\text { The quantitative criteria for the expected return of an IT project are not } \\
\text { only commonly used. Primarily because they are not capable to perform } \\
\text { of many expected functions and quality. }\end{array}$ & $\begin{array}{l}\text { Farbey et al., } \\
1992\end{array}$ \\
\hline 2 & $\begin{array}{l}\text { Failure of ERP projects has been effective at organizations bankruptcy } \\
\text { like FOX. }\end{array}$ & Bulkeley ,1996 \\
\hline 3 & $\begin{array}{l}\text { In a competitive market, organizations are forced to provide intangible } \\
\text { benefits to remain on the market. }\end{array}$ & Jolfsson, 1996 \\
\hline 4 & $\begin{array}{l}\text { Evaluating of ERP projects is challenging. It is not because it cannot be } \\
\text { justified, But also because they cannot be justified while a short period } \\
\text { that accountants and senior executives are expected to return in. }\end{array}$ & $\begin{array}{l}\text { Gunton T. } \\
\text {,1988 }\end{array}$ \\
\hline 5 & $\begin{array}{l}7 \% \text { reduction in production costs after ERP implementation in the } \\
\text { CARA aviation services company. }\end{array}$ & Stedman ,1999 \\
\hline 6 & $\begin{array}{l}\text { The cost reduction to the average value of } 1.5 \text { million } \$ \text { due to ERP } \\
\text { implementation after research from } 63 \text { companies }\end{array}$ & $\begin{array}{l}\text { META Group } \\
\text { Survey, } 1999\end{array}$ \\
\hline 7 & $\begin{array}{l}\text { ERP systems are a long-term strategic investment, and their } \\
\text { implementation is long-term affecting processes on entire organization. } \\
\text { The impact of ERP systems on organization's future performance, } \\
\text { requires examination beyond of the adoption process and examination } \\
\text { for a multi-year periods. }\end{array}$ & $\begin{array}{l}\text { Kallunki et al., } \\
2010\end{array}$ \\
\hline 8 & $\begin{array}{l}\text { Enterprise resource planning systems, is investing on infrastructure of } \\
\text { organizations that require a long time to return on investment. So if there } \\
\text { is no return on investment in the short term, it should not be considered } \\
\text { as a defeated one. }\end{array}$ & $\begin{array}{l}\text { Adel Azar and } \\
\text { Jahanian ,1390 }\end{array}$ \\
\hline
\end{tabular}

planning systems with organization's performance.

Table 2: the researches done on the relationship between enterprise resource planning systems with organization's performance. 


\section{2-2 Management Control System}

MCS is a system which gathers and uses information to evaluate the performance of different organizational resources - human, physical, financial and also of the organization as a whole considering the organizational strategies (Kallinikos ,2006 ).

MCS can be defined as a tool designed to assist the manager's decision-making consisting of both formal and informal forms of controls (Chenhall ,2003 ) Formal control consists of contractual obligations and formal organizational mechanisms and can be subdivided into outcome and behavior control mechanisms; informal or social control, on the other hand, relates to informal cultures and systems influencing members and is essentially based on mechanisms inducing selfregulation (Ouchi, 1979).

A management Control System (MCS) is a set of interrelated communication structures that facilitates the processing of information to assist managers in coordinating the parts and attaining the purpose of an organization on a continuous basis. Therefore, management control system is an interdisciplinary subject as it requires contribution from all branches concerned with the management in achieving a high level of quality, productivity and innovation (Chandra Das, 2011).

The following functions are involved in the management control system:

- Planning the activities of the

firm

- Coordinating the activities of the firm

- Communication information to various levels of organization structure

- Evaluating information and deciding the course of action.

- Influencing people to change their style of functioning

The purpose of MCS is to compare the actual results with the set standards in order to ensure that the work of each section of the firm is harmoniously accomplished with the 
works of the other section. A firm implements MCS to ensure that appropriate strategies are implemented to attain its goals. They also ensure that prompt actions are taken in case of emergency and uncertainly as well. They also help the management in decisionmaking process. Table (3) shows done researches on the relationship between enterprise resource planning systems with management control systems.

Table 3: Done researches on the relationship between enterprise resource planning systems with management control systems.

\begin{tabular}{|c|l|l|}
\hline NO. & \multicolumn{1}{|c|}{ Result of research } & \multicolumn{1}{|c|}{ Researcher name } \\
\hline 1 & $\begin{array}{l}\text { Organizational processes can be divided into three levels: strategic } \\
\text { planning, management control and operational control }\end{array}$ & Anthony, 1965 \\
\hline 2 & $\begin{array}{l}\text { Informal Controls with informal cultures and influenced systems of } \\
\text { members are connected. }\end{array}$ & Ouchi , 1979 \\
\hline 3 & $\begin{array}{l}\text { The main purpose of management control systems is to supply useful } \\
\text { information for decision-making, planning and evaluation. }\end{array}$ & $\begin{array}{l}\text { Merchant and } \\
\text { Otley ,2006 }\end{array}$ \\
\hline 4 & $\begin{array}{l}\text { Analysis of four decades of management control systems and its } \\
\text { division into six sections: planning, control, cybernetic, reward and } \\
\text { compensation, cultural and administrative controls }\end{array}$ & $\begin{array}{l}\text { Malmi and Brown } \\
, 2008\end{array}$ \\
\hline 5 & $\begin{array}{l}\text { The main purpose of management control systems, are displaying } \\
\text { solutions throughout the organization and guiding employee behaviors } \\
\text { toward designable methods In order to achieve organizational goals. }\end{array}$ & $\begin{array}{l}\text { Bhimani et } \\
\text { al.,2008 }\end{array}$ \\
\hline 7 & $\begin{array}{l}\text { Introduction of formal and Informal indicators of management control } \\
\text { in order to achieve a high level of quality, productivity and innovation } \\
\text { will require participation from all sectors. }\end{array}$ & $\begin{array}{l}\text { Kallunki et al., } \\
2010\end{array}$ \\
\hline
\end{tabular}

\section{2-3 Intangible performance}

David Norton (2012) reported that one of the reasons why organizations 
fail to implement their strategy, is to create change in the world, that the market share of tangible assets is changing to intangible assets. In this respect, considering the organization's intangible assets has the higher value for daily strategic planning. And neglecting that leads to the failure in achieving the goals of organization. If companies fail at applying intangible benefits, their profits have not been widely considered (Murphy \& Simon, 2002). Intangible assets are different with tangible assets. The first obvious difference is that tangible assets are such as money, machines and equipment. However intangible assets are such as the competence and management philosophy.

And Secondly, owners of tangible assets are usually specified; however, in the case of intangible assets, the matter is different (Edvinsson and Maloe,1997).

Machines and devices can be controlled by the organization. However, the organization cannot take the merits of their own employees or corporate culture, if any of the employees have decided to leave the organization.

The third difference is that tangible assets can be bought and sold. However, intangible assets are not necessarily like that (Edvinsson and Maloe,1997).

The fourth difference is that tangible assets can only be used for one purpose at the same time. However, intangible assets can be used for multiple purpose (Leo, 2001).

Table 4 shows done researches on the benefits of the intangible performance.

Table 4: Done researches on the benefits of intangible performance

\begin{tabular}{|c|l|l|}
\hline NO. & \multicolumn{1}{|c|}{ Result of research } & \multicolumn{1}{|c|}{ Researcher name } \\
\hline 1 & $\begin{array}{l}\text { Taking seriously the importance of benefits direction of IT } \\
\text { from the intangible toward tangible is increasing day by day. }\end{array}$ & $\begin{array}{l}\text { Dehning al.,2003 } \\
\text { et }\end{array}$ \\
\hline 2 & $\begin{array}{l}\text { All intangible assets of an organization accounts its } \\
\text { intellectual capitals. }\end{array}$ & $\begin{array}{l}\text { Lev and Schwartz } \\
, 1971\end{array}$ \\
\hline
\end{tabular}




\begin{tabular}{|c|c|c|}
\hline 3 & $\begin{array}{l}\text { Two main intangible benefits of IT investment are: } \\
\text { - present-based intangible benefits which include internal } \\
\text { improvements (the processes, decisions, and knowledge) and } \\
\text { customer relationships (quality of service, support, } \\
\text { warehouse and trade names). } \\
\text { - future-oriented intangible benefits, including foresight and } \\
\text { opportunities (in cases like markets, value chain integration } \\
\text { and participation) and the flexibility and adaptability (in } \\
\text { products, timely information and speed of re-engineering). }\end{array}$ & $\begin{array}{l}\text { Hares and Royle, } \\
1994\end{array}$ \\
\hline 4 & $\begin{array}{l}\text { The benefits are divided into two sections: } \\
\text { - tangible assets: cash, receivable accounts and properties } \\
\text { and equipment } \\
\text { - intangible assets: external and internal structure and } \\
\text { competence of staff }\end{array}$ & Sveiby ,1997 \\
\hline 5 & $\begin{array}{l}\text { Creating interest and value at the organization is indirect. } \\
\text { - intangible assets include learning new, improved } \\
\text { competence, improving business processes and customer } \\
\text { satisfaction. } \\
\text { - tangible benefits include revenue increment }\end{array}$ & Norton 2012 \\
\hline 6 & $\begin{array}{l}\text { Success factors in the institutions performance are } \\
\text { investigated by the four aspects: financial, non-financial, } \\
\text { tangible and intangible. }\end{array}$ & Lonnqvist ,2002 \\
\hline 7 & $\begin{array}{l}\text { According to the being more complicated of economic } \\
\text { relations, corporations reliance on mere financial measures, } \\
\text { to evaluate the paled performance and failure of these } \\
\text { measures, pale has been detected than recent time. }\end{array}$ & Zendehdel,1386 \\
\hline
\end{tabular}

In this paper, this is aimed that

\section{2-4 Conceptual model}

the impact of ERP systems are evaluated on management controlling systems organization's intangible performance. 
Secondly, the impact of formal and informal systems of management control are assessed, as a mediator variables can effect on the relationship between intangible organizational ERP systems.

Such careful assessment requires an identification of criteria, interaction and the amount of impressionability by each other.Hence the below conceptual model derived from the research of Kallunki et al. (2011) is provided to clearly define the relationships between variables.

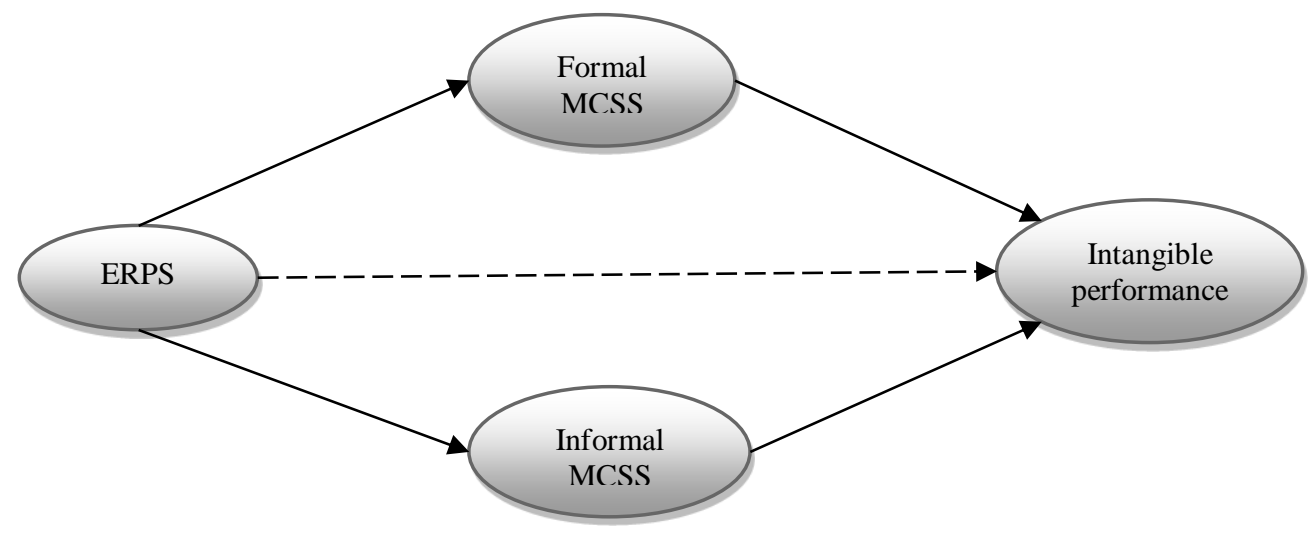

Figure 1 : Conceptual model

According to the above conceptual model, ERP systems have been considered as independent variables, and intangible Performance of Organizations has been considered as the dependent variable and formal and informal systems of management control have been considered as the mediator vvariables.

Hypothesis :
1 - There is significant relationship between ERP systems and intangible performance of organization.

2 - There is a significant relationship between ERP systems and formal management control systems.

3 - There is a significant relationship between ERP systems and informal management control systems.

4 - There is a significant relationship between the organization's 
intangible performance and the formal management control systems.

5 - There is a significant relationship between the organization's intangible performance and the informal management control systems.

6- Informal systems of management control mediate the relationship between ERP systems and the organization's intangible performance.

7- Formal systems of management control mediate the relationship between ERP systems and the organization's intangible performance.

\section{3- Data and research design}

This paper has an objective application, and since this research is seeking to identify relationships between variables, analysis between variables is conducted based on the Correlation research. And descriptive statistics are used to examine the characteristics of the population and demographics of respondents.

And structural equation modeling with using method of the Partial Least Squares and PLS software, are applied to test the validity of the assumptions and models.

Samples are operational, middle and senior managers of Iran Khodro company (Hall of L90 body), Saipa (Hall of Tyba body), Mapna Turbine Manufacturing and Engineering Company (Tuga) and Mapna engineering company of construction of turbine blades (Parto).

According to the investigations on the organizational structure and several company executives outlined above, the research community was estimated 180 people. The resolution is specified in the following table; and the number of sample is obtained 60 using Cochran formula. Table (5) performs the number of research community according to the surveyed companies:

Table 5: Number of research community according to the surveyed companies

\begin{tabular}{|l|c|c|c|c|c|}
\hline Company & $\begin{array}{c}\text { Iran Khodro (Hall ofL90 } \\
\text { body) }\end{array}$ & $\begin{array}{c}\text { Saipa (Hall Tyba } \\
\text { body) }\end{array}$ & Tuga & Parto & Sum \\
\hline
\end{tabular}




\begin{tabular}{|c|c|c|c|c|c|}
\hline $\begin{array}{c}\text { Number of } \\
\text { research } \\
\text { community }\end{array}$ & 62 & 54 & 41 & 23 & 180 \\
\hline
\end{tabular}

The data used in the study were collected by questionnaire. The questionnaire included items measuring the extent of the use of ERPS, formal and informal controls and the performance of the firm. A response scale is constructed with one to six Likert scale, as follows:

Table 6: Questionnaire rating based on Likert

\begin{tabular}{|c|c|c|c|c|c|c|}
\hline $\begin{array}{c}\text { The overall } \\
\text { shape }\end{array}$ & Very much & High & Average & Low & Very little & Unused \\
\hline Rating & 6 & 5 & 4 & 3 & 2 & 1 \\
\hline
\end{tabular}

\section{Research Indicators:}

- Module used for enterprise resource planning systems based on Kallunki et al. (2011) and Liaguat Hossain et al.( 2002) respectively.

- Effective Indicators at

applying of formal and informal systems of management control was derived from Kallunki et al. (2011).

- 6 factors in evaluating the intangible performance was derived from Lonnqvist research (2002) .

\section{Table 7: Research Indicators}

\begin{tabular}{|c|l|c|l|}
\hline \multicolumn{2}{|c|}{ Formal MCS } & \multicolumn{2}{c|}{ ERP } \\
\hline Items & \multicolumn{1}{|c|}{ Indicators } & Items & module \\
\hline B1 & Activity-Based Costing & A1 & Sales and marketing \\
\hline B2 & $\begin{array}{l}\text { Documenting of processes and } \\
\text { procedures }\end{array}$ & A2 & Procurement \\
\hline
\end{tabular}


Periódico do Núcleo de Estudos e Pesquisas sobre Gênero e Direito Centro de Ciências Jurídicas - Universidade Federal da Paraíba V. 8 - No 02 - Ano 2019 - Special Edition ISSN | 2179-7137 | http://periodicos.ufpb.br/ojs2/index.php/ged/index

\begin{tabular}{|c|c|c|c|}
\hline B3 & $\begin{array}{l}\text { Performance or operational evaluation } \\
\text { by outside auditors }\end{array}$ & A3 & $\begin{array}{l}\text { Supply chain } \\
\text { management (SCM) }\end{array}$ \\
\hline B4 & Statistical quality control of production & A4 & Inventory management \\
\hline B5 & $\begin{array}{l}\text { Inventory control and production } \\
\text { scheduling by means of operations } \\
\text { research techniques }\end{array}$ & A5 & Project management \\
\hline B6 & Regular evaluation of staff & A6 & $\begin{array}{l}\text { Production } \\
\text { management }\end{array}$ \\
\hline B7 & Regular evaluation of managers & A7 & $\begin{array}{l}\text { Service and } \\
\text { maintenance }\end{array}$ \\
\hline \multirow[t]{7}{*}{ B8 } & $\begin{array}{l}\text { Use of internal rate of return/present } \\
\text { value in evaluating investments }\end{array}$ & A8 & $\begin{array}{l}\text { Quality control } \\
\text { management }\end{array}$ \\
\hline & - & A9 & $\begin{array}{l}\text { Customer relationship } \\
\text { management(CRM) }\end{array}$ \\
\hline & - & A10 & $\begin{array}{l}\text { Human resource } \\
\text { management (HRM) }\end{array}$ \\
\hline & - & A11 & Financial management \\
\hline & - & A12 & $\begin{array}{l}\text { Research and } \\
\text { development } \\
\text { management }\end{array}$ \\
\hline & - & A13 & Budgeting and planning \\
\hline & - & A14 & $\begin{array}{l}\text { Management of } \\
\text { Performance } \\
\text { Assessment }\end{array}$ \\
\hline \multicolumn{2}{|r|}{ Performance } & \multicolumn{2}{|r|}{ InFormal MCS } \\
\hline Items & Indicators & Items & Indicators \\
\hline V1 & Competencies & $\mathrm{C} 1$ & $\begin{array}{l}\text { An emphasis on } \\
\text { consensus-seeking, staff } \\
\text { participative decision } \\
\text { making }\end{array}$ \\
\hline
\end{tabular}


Periódico do Núcleo de Estudos e Pesquisas sobre Gênero e Direito Centro de Ciências Jurídicas - Universidade Federal da Paraíba V. 8 - No 02 - Ano 2019 - Special Edition ISSN | 2179-7137 | http://periodicos.ufpb.br/ojs2/index.php/ged/index

\begin{tabular}{|l|l|l|l|}
\hline V2 & Customer satisfaction & C2 & $\begin{array}{l}\text { Open channels of } \\
\text { communication and free } \\
\text { flow of information }\end{array}$ \\
\hline V3 & Customer retention & C3 & $\begin{array}{l}\text { Easy informal access to } \\
\text { senior managers }\end{array}$ \\
\hline V4 & Innovation & C4 & $\begin{array}{l}\text { Managers with } \\
\text { information } \\
\text { colleagues }\end{array}$ \\
\hline V5 & Motivation & C5 & $\begin{array}{l}\text { Fast reaction to take } \\
\text { advantage of } \\
\text { unexpected } \\
\text { opportunities }\end{array}$ \\
\hline V6 & Personnel satasifaction & C6 & $\begin{array}{l}\text { Current corporate } \\
\text { culture encourages } \\
\text { informal signaling of } \\
\text { potential problems } \\
\text { Composite reliability }\end{array}$ \\
\hline
\end{tabular}

\section{4 - Analysis of data}

In this study, to ensure the validity of the survey questionnaire, this questionnaire reviewed by experts, and finally with applying the required changes, the validity of the questionnaire was approved.
After validation, a total of 30 questionnaires were distributed to pilots. The reliability was achieved by using SPSS software and the Cronbach's Alpha giving rise to the level of 0.838 indicating to the high reliability rate, as follows:

Table 8: table of Cronbach's Alpha

\begin{tabular}{|c|c|c|c|}
\hline $\begin{array}{c}\text { Variabl } \\
\mathrm{e}\end{array}$ & Indicators & $\begin{array}{c}\text { Cronbach's } \\
\text { Alpha }\end{array}$ & $\begin{array}{c}\text { Cronbach's Alpha- } \\
\text { total }\end{array}$ \\
\hline \multicolumn{2}{|l|}{ ERPS } & 0.781 & \multirow{2}{*}{0.863} \\
\hline & Formal MCS & 0.824 & \\
\hline
\end{tabular}




\begin{tabular}{|c|c|c|}
\hline & Informal MCS & 0.889 \\
\hline \multicolumn{2}{|l|}{ MCS } & 0.904 \\
\hline & Competencies & 0.7 \\
\hline & Customer satisfaction & 0.701 \\
\hline & Customer retention & 0.731 \\
\hline & Innovation & 0.693 \\
\hline & Motivation & 0.72 \\
\hline & Personnel satisfaction & 0.728 \\
\hline \multicolumn{2}{|c|}{ Intangible performance } & 0.838 \\
\hline
\end{tabular}

\subsection{The measurement model test}

In order to achieve convergent validity and correlation factor, the compound reliability test and meanvariance root were assessed. The reliability Higher than 0.8 with the average root of variance of 0.5 ,at least, are two necessary conditions for convergent validity and correlation of a structure. As shown in the table below, the reliability for all structures are between 0.819 to 0.94 , which indicates a high convergence validity.

Factor Loadings Larger than 0.5 indicates to have proper reliability; according to the table it can be seen that all structures have factor loadings between 0.50 and 0.86 showing a high correlation.

Table 9: The structural model test

\begin{tabular}{|c|c|c|c|c|c|c|c|c|c|}
\hline $\begin{array}{c}\text { mean- } \\
\text { varian } \\
\text { ce } \\
\text { root }\end{array}$ & $\begin{array}{l}\text { compou } \\
\text { nd } \\
\text { reliabilit } \\
\text { y }\end{array}$ & $\begin{array}{c}\text { Factor } \\
\text { Loadi } \\
\text { ng }\end{array}$ & $\begin{array}{l}\text { Ite } \\
\text { ms }\end{array}$ & $\begin{array}{c}\text { variab } \\
\text { le }\end{array}$ & $\begin{array}{c}\text { mean- } \\
\text { varian } \\
\text { ce } \\
\text { root }\end{array}$ & $\begin{array}{l}\text { compou } \\
\text { nd } \\
\text { reliabilit } \\
\text { y }\end{array}$ & $\begin{array}{c}\text { Factor } \\
\text { Loadi } \\
\text { ng }\end{array}$ & $\begin{array}{l}\text { Ite } \\
\text { ms }\end{array}$ & $\begin{array}{c}\text { variab } \\
\text { le }\end{array}$ \\
\hline \multirow{2}{*}{0.8} & \multirow{2}{*}{0.937} & $\begin{array}{c}0.783 \\
9\end{array}$ & B1 & \multirow{2}{*}{ 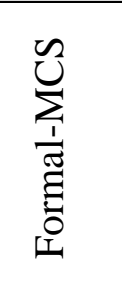 } & \multirow{2}{*}{0.78} & \multirow{2}{*}{0.940} & 0.792 & A1 & \multirow{2}{*}{$\frac{\vec{a}}{\underline{r l}}$} \\
\hline & & $\begin{array}{c}0.821 \\
6\end{array}$ & B2 & & & & 0.772 & A3 & \\
\hline
\end{tabular}


Periódico do Núcleo de Estudos e Pesquisas sobre Gênero e Direito Centro de Ciências Jurídicas - Universidade Federal da Paraíba V. 8 - $\mathrm{N}^{\circ} 02$ - Ano 2019 - Special Edition ISSN | 2179-7137 | http://periodicos.ufpb.br/ojs2/index.php/ged/index

\begin{tabular}{|c|c|c|c|c|c|c|c|c|c|}
\hline & & $\begin{array}{c}0.793 \\
5\end{array}$ & B3 & & & & 0.737 & A4 & \\
\hline & & $\begin{array}{c}0.734 \\
5\end{array}$ & B4 & & & & 0.778 & A5 & \\
\hline & & $\begin{array}{c}0.826 \\
1\end{array}$ & B5 & & & & 0.703 & A6 & \\
\hline & & $\begin{array}{c}0.869 \\
7\end{array}$ & B6 & & & & 0.780 & A7 & \\
\hline & & $\begin{array}{c}0.818 \\
9\end{array}$ & B7 & & & & 0.736 & A8 & \\
\hline & & $\begin{array}{c}0.805 \\
0\end{array}$ & B8 & & & & 0.754 & A9 & \\
\hline \multirow{10}{*}{0.8} & \multirow{6}{*}{0.919} & $\begin{array}{c}0.844 \\
2\end{array}$ & $\mathrm{C} 1$ & \multirow{6}{*}{ 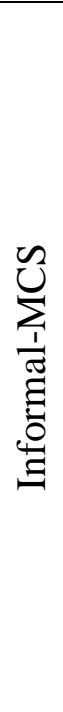 } & & & 0.779 & A10 & \\
\hline & & 0.83 & $\mathrm{C} 2$ & & & & 0.825 & A11 & \\
\hline & & 0.786 & C3 & & & & 0.793 & A12 & \\
\hline & & $\begin{array}{c}0.828 \\
9\end{array}$ & $\mathrm{C} 4$ & & & & 0.746 & A13 & \\
\hline & & $\begin{array}{c}0.820 \\
1\end{array}$ & C5 & & & & 0.758 & A14 & \\
\hline & & $\begin{array}{c}0.736 \\
1\end{array}$ & C6 & & \multirow{5}{*}{0.66} & \multirow{5}{*}{0.819} & $\begin{array}{c}0.808 \\
6\end{array}$ & V1 & \multirow{5}{*}{ 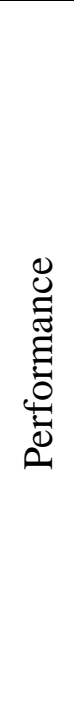 } \\
\hline & & & & - & & & $\begin{array}{c}0.723 \\
3\end{array}$ & V2 & \\
\hline & & & & - & & & $\begin{array}{c}0.580 \\
5\end{array}$ & V3 & \\
\hline & & & & - & & & $\begin{array}{c}0.717 \\
0\end{array}$ & V4 & \\
\hline & & & & - & & & $\begin{array}{c}0.579 \\
7\end{array}$ & V5 & \\
\hline
\end{tabular}




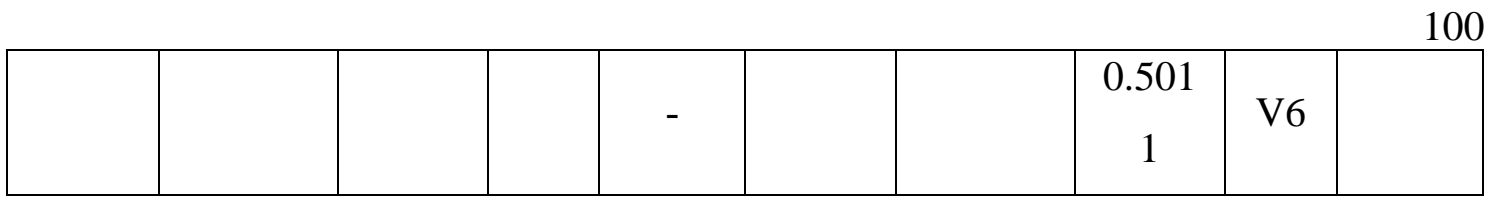

\subsection{Assessment of the structural} model control systems on the intangible performance has been completely examined.

and formal and informal management

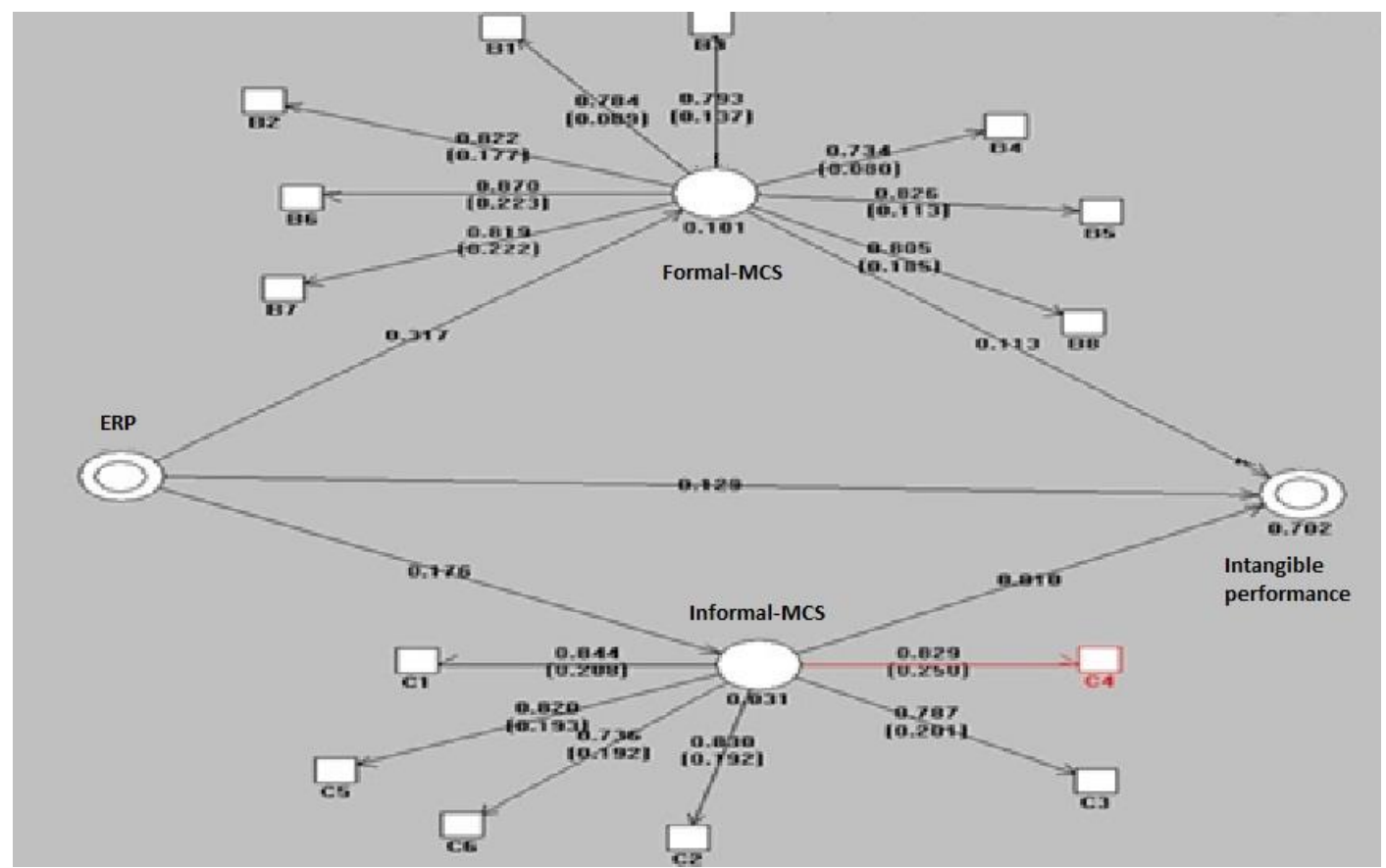

Figure 2 : Structural model results

In below table the values of the path coefficients and their significance for each hypothesis is reviewed.

$\mathrm{T}$ statistic values are considered to assess the significance of the path coefficients. it will be considered significance, provided that the coefficient is bigger than 1.96 . 


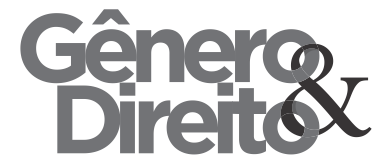

Periódico do Núcleo de Estudos e Pesquisas sobre Gênero e Direito

Centro de Ciências Jurídicas - Universidade Federal da Paraíba V. 8 - No 02 - Ano 2019 - Special Edition ISSN | 2179-7137 | http://periodicos.ufpb.br/ojs2/index.php/ged/index

\begin{tabular}{|c|c|c|c|c|c|}
\hline \multicolumn{3}{|c|}{ Hypothesis } & \multirow{2}{*}{\begin{tabular}{|c|}
$\begin{array}{c}\text { Path } \\
\text { coefficients }\end{array}$ \\
0.129
\end{tabular}} & \multirow{2}{*}{$\begin{array}{c}\text { T statistic } \\
\text { value }\end{array}$} & \multirow{2}{*}{$\begin{array}{c}\text { Result } \\
\text { confirmed }\end{array}$} \\
\hline ERP & $\rightarrow$ & Intangible performance & & & \\
\hline ERP & $\rightarrow$ & Formal-MCS & 0.317 & 2.338 & confirmed \\
\hline ERP & $\rightarrow$ & Informal-MCS & 0.176 & 1.746 & Not confirmed \\
\hline $\begin{array}{r}\text { Formal- } \\
\text { MCS }\end{array}$ & $\rightarrow$ & Intangible performance & 0.113 & 14.576 & confirmed \\
\hline $\begin{array}{r}\text { Informal- } \\
\text { MCS }\end{array}$ & $\rightarrow$ & Intangible performance & 0.810 & 1.057 & Not confirmed \\
\hline $\begin{array}{r}\text { Informal- } \\
\text { MCS }\end{array}$ & $\rightarrow$ & $\begin{array}{l}\text { mediate the relationship } \\
\text { between ERPs and } \\
\text { intangible performance }\end{array}$ & $\begin{array}{l}* \text { Direct } \\
\text { effect } \\
: 0.810 \\
* \text { Indirect } \\
\text { effect:0.976 }\end{array}$ & - & confirmed \\
\hline $\begin{array}{l}\text { Formal- } \\
\text { MCS }\end{array}$ & $\rightarrow$ & $\begin{array}{l}\text { mediate the relationship } \\
\text { between ERPs and } \\
\text { intangible performance }\end{array}$ & $\begin{array}{l}* \text { Direct } \\
\text { effect } \\
: 0.113 \\
* \text { Indirect } \\
\text { effect }: 0.43\end{array}$ & - & confirmed \\
\hline
\end{tabular}

\section{According to the above table:}

1- There is a relationship between ERP system and the intangible performance of an organization. Because the Obtained T statistic value was 1.99 that is greater than 1.96 .

2- There is a relationship between ERP system and formal management control systems. Because the Obtained T statistic value was 2.33 that is greater than 1.96 .

3- There is not a relationship between ERP system and informal management control systems. Because the Obtained $\mathrm{T}$ statistic value was 1.74 that is greater than 1.96 .

4- There is a relationship between formal management control 
systems and intangible performance of an organization. Because the Obtained $\mathrm{T}$ statistic value was 14.57 that is greater than 1.96 .

5- there is not a relationship between informal management control systems and intangible function of an organization. Because the Obtained $\mathrm{T}$ statistic value was 1.057 that is greater than 1.96 .

6- Informal management control systems mediate the relationship between ERP systems and intangible organizational performance. Because the informal system of management control due to greater non-indirect impact factor of 0.976 than the direct impact factor of 0.810 implies on intermediary of above relationship.

7- Formal management control systems mediate the relationship between ERP systems and intangible organizational performance. Because the formal system of management control due to greater indirect impact factor of 0.43 than the direct impact factor of 0.113 implies on intermediary of above relationship.

\section{5 - Conclusion}

\subsection{Evaluation of the results of the} PLS software:
1- The first hypothesis of the study examines the relationship between ERP systems variables and the organization's intangible performance. The results of the analysis of data indicate impact of ERP systems on organizational intangible performance with respect to the significance level of $T$ (1.99). The research hypothesis's findings were in good agreement with (Marcus and Robbie, 1998), (O'Leary,2000), (Grabski and Leech, 2007) and (Kallunki et al.,2010).

2- The second hypothesis of the study examines the relationship between ERP systems variables and the formal management control systems. The results of the analysis of data indicate impact of ERP systems on the formal management control systems with respect to the significance level of $\mathrm{T}$ (2.38). The research hypothesis's findings were in good agreement with (Kallunki et al.,2010), (Chenhall and Morris, 1995) and (Khandwalla, 1972).

3- The third hypothesis of the study examines the relationship between ERP systems variables and the informal management control systems. The results of the analysis of data do not indicate impact of ERP systems on the 
formal systems of management control with respect to the significance level of $\mathrm{T}(1.746)$.

4- The fourth hypothesis of the study examines the relationship between variables of formal management control systems and organization's intangible performance. The results of the analysis of data indicate impact of formal management control systems on organization's intangible performance with respect to the significance level of $\mathrm{T}$ (14.576). The research hypothesis's findings were in good agreement with (Kallunki et al.,2010), (Simons ,2000) and (Widener ,2007).

5- The fifth hypothesis of the study examines the relationship between variables of informal management control systems and organization's intangible performance. The results of the analysis of data do not indicate impact of informal systems of management control on organization's intangible performance with respect to the significance level of $\mathrm{T}$ (1.057).

6- The sixth hypothesis of the study examines the effect of intermediary of informal management control systems on the relationship between ERP systems and the organization's intangible performance.
The results of the analysis of data indicate impact of intermediary of informal management control systems on the relationship between ERP systems and the organization's intangible performance with respect to direct and indirect regression coefficient of 0.810 and 0.976 respectively.

7- The seventh hypothesis of the study examines the effect of intermediary of formal management control systems on the relationship between ERP systems and the organization's intangible performance. The results of the analysis of data indicate impact of intermediary of formal management control systems on the relationship between ERP systems and the organization's intangible performance with respect to direct and indirect regression coefficient of 0.113 and 0.43 respectively. The research hypothesis's findings were in good agreement with (Kallunki et al.,2010), (Chapman, 2005) and (Chapman and Kihn, 2009).

\section{5-2 research proposals:}

As regards formal management control systems expressed in this research include activity-based costing, 
documenting of processes and procedures, operation or performance evaluation by the auditors outside the organization, Statistical quality control of production, Inventory control and production scheduling by means of operations research techniques ,Regular evaluation of staff and managers, using rate of return or present value of capital assets. Therefore, operational managers and senior supervisors of researched company are recommended to improve any of the aforementioned factors , organization's intangible performance in the areas of competency, customer satisfaction, customer retention, creativity, motivation of employees, and employee satisfaction .

According to the observed effects of intermediator of Informal systems of management control on the relationship between ERP systems and organization's intangible performance, operational managers and senior supervisors of researched company are recommended that Given the emphasis on consensus criteria, Employee participation in decision making, open channels of communication and the free flow of information, unofficial easy access to senior managers, Sharing information with colleagues and managers, rapid response to unexpected opportunities and encouraging managers to develop new ideas, even if it is outside the scope of their responsibility, take action to improve these components through improving informal management control systems, improving the relationship between ERP systems on intangible organizational performance.

\subsection{Recommendations for Future}

\section{Research}

1- evaluation of organizational performance through Financial and intangible aspects with respect to the model of Long West (2002)

2- evaluation of organizational performance through tangible and nonfinancial aspects with respect to the model of Long West (2002)

3- evaluation of organizational performance through tangible and financial aspects with respect to the model of Long West (2002)

4- evaluation of applying this study at one organization or organizations more resembling together culturally.

\section{References}


Azar, Adel; Jahanian, Reza (2011).

Reengineering Business Processes:

Concepts and Case studies. Organization for the Study and Compilation of Humanities Books of Universities (samt).

Tavakoli, Ahmad; Taghikhah, Firoozeh. (2012). Explain the importance of designing appropriate comprehensive indicators to measure the impact of the organization's planning system on the performance of organizations. National Conference on Modern Management: 26-08-2012.

Roosta, Ahmad (2010). Quality of Service Provision and Customer Satisfaction Guidelines. Second International Conference on Quality and Productivity Management in the Globalization Attitude, Ministry of Industry and Mines.

Naseri Taheri, Parviz; Taheri Ardakani, Hasan and Khalou Bagheri, Hojjat A. (2008). ERP market characteristics in Iran. Tadbir, No. 195: page 42-48.

Aladwani,A.(1985).

Change management strategies for successful ERP implementation.
Business Process Management Journal 7

(3):266-275.

Al-Mashari,M.(2003).Enterprise

resource planning (ERP) systems: a research agenda. Industrial Management \& Data Systems 103 (1):22-27.

Amid,A., Moalagh, $\quad$ M., ZareRavasan,A.(2012). Identification and classification of ERP critical failure factors in Iranian industries.Information Systems 37:227-237.

Anthony,R.N.,Govindarajan,V.(2007). Management Control Systems.Chicago : McGra -Hill Irwin.

Anthony,R.N.(1965).A Framework for Analysis. Planning and Control Systems. Boston, MA, Harvard Business School Press.

Dechow,N.Mouritsen,J.(2005).Enterpris e resource planning systems, management control and thequest for integration.Acc Organ Soc;30:691-733.

Davenport,T.H.(1998).Putting the enterprise into the enterprise system. Harvard Business Review, 76( 4):121131. 
Dehning,B.Richardson, V.J.Zmud,R.W.( 2003).The value relevance of announcements of transformational information technology investments. MIS Quarterly, 27(4): 637-656.

DeLone,W.D.McLean,E.R.(2003).The

DeLone and McLean model of information systems success: a ten-year update. Journal of Management Information Systems 19 (4): 9-30.

Desouza,K.,Evaristo,J.(2006).Project

management offices: a case of knowledgebased archetypes.

International Journal of Information Management 26 (5): 414-423.

David,P.,Norton.(2012).Managing

Business Performance: The Challenge of Intangible Assets. Prepared for WPI Events September - October.

Emigh,J.(1999).Net present value.

ComputerWorld, 26 July, 33(30): 52-53.

Farbey,B.,Land,F.F,Targett,D.(1995).A taxonomy of information systems applications:
Lev,B.Schwartz,A.(1971).On the use of the economic concepts of human capital in financial statements. The Accounting Review January:103-112

Lev,B.(2001).Intangibles: Management, Measurement, and Reporting.Washington D.C.

Lonnqvist,A.,Mettane,P.(2002).Criteria of Sound Intellectual Capital Measures ,Proceedings of the $2^{\text {nd }}$ International Workshop on Performance Measurement. Hanover,Germany , June6-7:147-157.

META Group Survey(Extract): ERM Solutions and Their Value. Meta Group.

Malmi,T.,Brown,DA.(2008).Manageme nt control systems as a package opportunities, challenges and research directions .Management Accounting Research;19:287-300.

Mahmood,M.A.,Szewczak,E.J.(1999). Measuring Information Technology Payoff: Contemporary Approaches. Hershey, PA: Idea Group Publishing..

Mabert,V.A.,Soni,A.,Venkataramanan, M.A.(2001).Enterprise resource 
planning: Measuring value. Production and Inventory Management Journal, 42(3/4):46-51.

Markus,M.L.,Tanis,C.(2000).The

enterprise system experience: from adoption to success, in: R.W. Zmud (Ed.), Framing the Domains of IT Management: Projecting the Future through the Past.Pinnaflex Educational Resources Inc., Cincinnati:173-207.

Merchant,K.A.,Otley,D.A.(2006).revie $\mathrm{w}$ of the literature on control and accountability. In: Chapman C, Hopwood A, Shields M, editors. The Handbook of Management Account Research. Elsevier Press.

\section{Markus,M.L.,Axline}

S.,Petrie

D.,Tanis,C.(2000).Learning from adopters' experiences with ERP: problems encountered and success achieved. Journal of Information Technology 15 (4) : 245-265.

Tsai,W.,Shaw,M.,Fan,Y.,Liu,J.,Lee

K.,Chen,H.(2011).An empirical investigation of the impacts of internal/external facilitators on the project success of ERP. a structural
107

equationmodel. Decision Support

Systems 50 (2):480-490.

Peters,T.,Waterman,R.H.(1982).In

Search Of Excellence

summary.McKinsey 7-S model.

Waters,D.(1996).Operation

Management. Addison-Wesley.

Widener,S.(2007).An empirical analysis of the levers of control framework. Acc Organ Soc;32:757-88.

Wilkes University.(2013).Performance Management-Dictionary of Competencies:7-17.

Wold,H.(1985).Systems analysis by partial least squares. In: Nijkamp P, Leitner N, Wrigley N, editors. Measuring the Unmeasurable. Dordrecht: Marinus Nijhoff. 